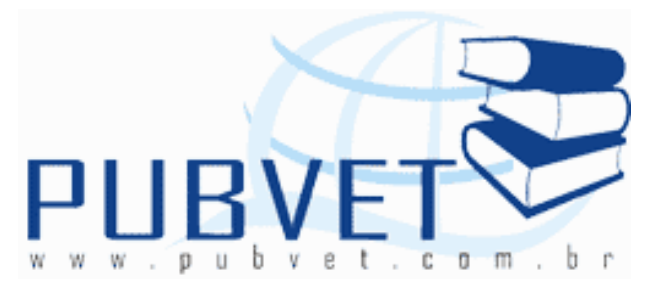

PUBVET, Publicações em Medicina Veterinária e Zootecnia.

\title{
Impactos da seleção genética na qualidade da carne suína
}

Priscila Furtado Campos ${ }^{1}$, Ana Paula Cardoso Gomide ${ }^{1}$, Bruno Andreatta Scottá ${ }^{1}$, Carlota Coelho Barroca ${ }^{1}$, Marcos Henrique Soares ${ }^{2}$

1 - Doutorandos do programa de pós-graduação em Zootecnia-UFV, Viçosa, MG. pricampos2@yahoo.com.br

2 - Graduando em Zootecnia - UFV, Viçosa, MG.

\section{Resumo}

Os avanços no melhoramento genético de suínos que ocorreram nos últimos anos têm levado a um aumento do ganho de peso, diminuição na conversão alimentar e na espessura de toucinho na carcaça dos suínos. Porém essa intensa seleção tem causado alguns impactos negativos na qualidade final da carne. Objetivou-se por meio deste trabalho discutir os impactos da seleção genética sobre as características qualitativas da carne suína. Animais portadores do gene halotano apresentam carne com qualidade inferior, uma vez que esse gene está relacionado ao aparecimento de carne PSE (pálida, mole e exsudativa), apresentando coloração pálida e baixa capacidade de retenção de água, sendo um tipo de carne que não é bem aceito no mercado devido suas características visuais e organolépticas. O gene da carne ácida promove queda no $\mathrm{pH}$ final da carne, ao redor de 5.4, o que acarreta decréscimo no rendimento industrial durante o processamento de produtos curados e cozidos. O tipo de fibra muscular também influencia a qualidade da 
CAMPOS, P.F. et al. Impactos da seleção genética na qualidade da carne suína. PUBVET, Londrina, V. 8, N. 2, Ed. 251, Art. 1659, Janeiro, 2014.

carne, e os suínos modernos apresentam maior proporção de fibras glicolíticas, portanto carne mais clara e com menor capacidade de retenção de água. 0 marmoreio é uma das principais características relacionada à maciez e suculência da carne, porém observa-se que raças com alto rendimento de carne, apresentam menor teor de gordura intramuscular. Dessa forma a seleção genética para aumento na quantidade de carne na carcaça levou a uma diminuição na taxa de marmoreio da carne. Conclui-se que, é de extrema importância que se tenha um programa de melhoramento genético voltado não somente para a qualidade da carcaça, mas também que atenda os requisitos exigidos para uma melhor qualidade da carne.

Palavras-chave: espessura de toucinho, gene halotano, gene da carne ácida, tipo de fibra muscular.

\section{Impacts of genetic selection in meat quality of pigs}

\section{Abstract}

Advances in breeding pigs that have occurred in recent years have led to an increase in weight gain, decreased feed conversion and back fat thickness in swine. But this intense selection has caused some negative impacts on the final quality of the meat. The objective of this work was discussing the impact of genetic selection on the meat quality characteristics of pigs. Halothane gene carrier animals have lower meat quality, since this gene is related to the onset of PSE meat (pale, soft, exudative) presenting pale and low water retention capacity, one type of meat is not well accepted in the market because of their visual and organoleptic characteristics. The gene meat acidic $\mathrm{pH}$ promotes reduction in final $\mathrm{pH}$ meat around 5.4, which causes decrease in yield during the industrial processing and cooked cured products. The type of muscle fiber also affects the quality of meal; modern pigs have a higher proportion of modern glycolytic fibers, so meat lighter and less ability to retain water. The marbling is one of the main features related to tenderness and juiciness, but notes that breeds with high meat yield, have lower intramuscular fat content. 
CAMPOS, P.F. et al. Impactos da seleção genética na qualidade da carne suína. PUBVET, Londrina, V. 8, N. 2, Ed. 251, Art. 1659, Janeiro, 2014.

Thus genetic selection for increasing the quantity of meat in the carcass led to a decrease in the rate of marbling. We conclude that it is important to have a breeding program aimed not only for the quality of housing, but also meets the requirements for better meat quality.

Keywords: back fat thickness, gene acidic flesh, halothane gene, muscle fiber type

\section{Introdução}

Entende-se por qualidade de um produto, o conjunto de atributos que satisfaz às necessidades do consumidor, chegando até a ultrapassar as suas expectativas iniciais. A qualidade da carne com relação ao conceito muda de acordo com o mercado, isto é, da cultura predominante e da faixa de renda do segmento de consumidores a ser atingido.

Atualmente, a qualidade da carne representa uma das principais preocupações, especialmente para consumidores mais exigentes. De modo geral, pode-se dizer que a qualidade da carne e da carcaça depende da interação de fatores intrínsecos e extrínsecos. Os fatores intrínsecos mais importantes são a genética, o manejo alimentar, a idade e o sexo. Entre os fatores extrínsecos são muito importantes às condições de abate, desde a saída dos animais da propriedade até a entrada das carcaças nas câmaras frias, o tipo de cozimento e os métodos de conservação.

Os principais atributos avaliados na carne para determinar sua qualidade são a cor, a capacidade de retenção de água e a textura. A cor é um dos fatores mais importantes na percepção do consumidor quanto à qualidade da carne, pois é uma característica que influencia tanto na escolha inicial do produto como na aceitação no momento do consumo.

Há vários fatores pré-abate que podem influenciar a coloração da carcaça, mas no abatedouro, os principais fatores são o atordoamento, o resfriamento e o congelamento. Hematomas e hemorragias, que podem levar à condenação das carcaças, são causados principalmente pelo inadequado 
CAMPOS, P.F. et al. Impactos da seleção genética na qualidade da carne suína. PUBVET, Londrina, V. 8, N. 2, Ed. 251, Art. 1659, Janeiro, 2014.

manejo pré-abate e intensificados por alguns procedimentos durante o próprio processamento.

A maciez ou textura é um dos critérios de qualidade mais importantes em qualquer tipo de carne, pois está associada à satisfação final do consumidor. Trata-se de um parâmetro sensorial que possui como atributos primários, maciez, coesividade, viscosidade e elasticidade, e como secundários, gomosidade, mastigabilidade, suculência, fraturabilidade e adesividade.

As propriedades da carne fresca determinam sua utilidade para comercialização, sua aparência para o consumo e sua adaptabilidade para processamentos industriais. Dentre as características mais importantes destacam-se a capacidade de retenção de água (C.R.A), cor, firmeza, textura e estrutura (DABÉS, 2001).

O melhoramento genético nos últimos anos tem contribuído para melhoras no ganho de peso, conversão alimentar, deposição de carne magra e porcentagem de gordura na carcaça dos animais. Porém essa intensa seleção tem causado impactos nas características de carcaça, influenciando diretamente na qualidade final da carne. Essa revisão tem por objetivo discutir os impactos da seleção genética sobre as características qualitativas da carne suína.

\section{Melhoramento Genético em suínos}

As chamadas raças nacionais, destacando-se o Piau, Tatu, Canastra, Nilo, Caruncho, Pereira e Pirapitinga, foram originadas de raças introduzidas no Brasil em 1532, por Martin Afonso de Souza.

Em 1958 foi criada a Associação Brasileira de Criadores de Suínos $(A B C S)$, onde teve início o controle genealógico dos suínos e a importação de raças exóticas, com o objetivo de melhorar a produtividade da criação e aumentar a produção de carne, já que a banha, principal produto das raças nativas, começava a perder espaço para os óleos vegetais que apresentava as vantagens de ser líquido e vir numa embalagem apropriada, pronta para o uso 
CAMPOS, P.F. et al. Impactos da seleção genética na qualidade da carne suína. PUBVET, Londrina, V. 8, N. 2, Ed. 251, Art. 1659, Janeiro, 2014.

(VALENTINE, 2005). Além disso, estudos médicos e nutricionais posteriores agregaram ainda a questão da presença de colesterol e outros fatores de risco para a saúde na gordura suína. Dessa forma, os produtores passaram a contar com as raças Duroc Jersey, Wessex, Saddleback, Hampshire, Berkshire, Poland China, Large Black, Montana e Tamworth.

Numa segunda fase de grande importação, com início na década de 60, chegaram às raças brancas Landrace e Large White, além de alguns exemplares de Pietrain. Porém, o marco inicial do melhoramento genético no Brasil se deu com o Teste de Progênie (TP), introduzido em 1970. O TP avaliava o potencial genético dos pais, especialmente dos machos, mediante teste de desempenho e da carcaça dos filhos, pois até então o melhoramento genético era feito exclusivamente por meio da introdução de material genético de fora.

Na década seguinte, começaram a chegar ao país empresas de genética que trouxeram um novo conceito de criação. Ao invés do criador fazer o cruzamento entre duas raças puras, foram introduzidos suínos híbridos, formados por várias raças, agregando características para criar um animal ideal em prolificidade, velocidade em ganho de peso, taxa de conversão alimentar, porcentagem de carne magra na carcaça e qualidade da carne. (VALENTINE, 2005).

O desempenho zootécnico dos suínos apresentou melhoras significativas nas últimas décadas. A idade à puberdade de fêmeas e machos diminuiu de 7 a 8 para 4 a 5 meses, e o número de leitões nascidos por leitegada aumentou de 7 a 8 para 10 a 12 leitões. O aumento da prolificidade, associado à redução dos períodos de aleitamento, permitiu aumentar a produtividade das porcas de 15 a 16 para 22 a 24 leitões por ano. A taxa de crescimento, a conversão alimentar e a produção de carne por animal abatido também mudaram significativamente. Enquanto na década de 1970 os suínos alcançavam $100 \mathrm{~kg}$ de peso vivo aos 180 dias de idade, conversão alimentar em torno de $3,5 \mathrm{~kg}$ de ração por $\mathrm{kg}$ de ganho em peso, e rendimento de carne inferior a $48 \%$, atualmente os suínos atingem $100 \mathrm{~kg}$ de peso vivo com 150 a 160 dias de 
CAMPOS, P.F. et al. Impactos da seleção genética na qualidade da carne suína. PUBVET, Londrina, V. 8, N. 2, Ed. 251, Art. 1659, Janeiro, 2014.

idade, com conversão alimentar, do nascimento ao abate, de 2,50 a 2,60 kg de ração consumida por $\mathrm{kg}$ de ganho em peso, e rendimento de carne de 53-55 $\%$ nos abatedouros brasileiros de suínos. Tais níveis de desempenho indicam que, se há 20 a 30 anos produziam-se de 500 a $600 \mathrm{~kg}$ de carne por ano da progênie de uma fêmea de plantel, necessitando-se para isso de 5.000 a 6.000 $\mathrm{kg}$ de ração, atualmente, com a mesma quantidade de ração produzem-se 800 a $900 \mathrm{~kg}$ de carne por ano da mesma unidade de produção, assumindo-se um rendimento industrial de carcaça de $75 \%$. Isto representa um aumento de 50 a 60 \% na eficiência de produção de carne, resultando num aumento de 1.250 a 1.500 para 2.000 a $2.250 \mathrm{~kg}$ de carne produzida pela progênie de uma fêmea de plantel, considerando-se como sendo de 2,5 anos a sua vida reprodutiva.

Esse aumento na eficiência produtiva dos suínos resultou de mudanças na estrutura de obtenção do melhoramento genético dos suínos, que, a partir de 1970 passou a ser estratificada em granjas núcleos, multiplicadoras e de produção de suínos para o abate. Nesta estrutura, os ganhos genéticos da seleção são intensificados nas granjas núcleos e expandidos nas granjas multiplicadoras, que, aos ganhos genéticos aditivos, acrescentam ganhos epistáticos e de complementaridade aos reprodutores. Estes animais, geneticamente "carregados", são transferidos para granjas comerciais, onde podem expressar o seu potencial genético na produção de suínos para o abate.

A melhora na eficiência de produção dos suínos deve-se também às mudanças nas condições de criação, incluindo-se as instalações, o nível nutricional dos alimentos, o manejo aplicado e o controle das doenças.

\section{Problemas associados ao melhoramento genético}

A intensa seleção genética que procurou qualificar a carcaça com características conformacionais e de rendimento, não considerou efetivamente as características funcionais da carne para seu emprego pela indústria processadora, o que abriu caminho para a ocorrência de defeitos tecnológicos na carne. 
CAMPOS, P.F. et al. Impactos da seleção genética na qualidade da carne suína. PUBVET, Londrina, V. 8, N. 2, Ed. 251, Art. 1659, Janeiro, 2014.

\subsection{Redução da espessura de toucinho}

A característica mais utilizada na avaliação da carcaça do animal é a espessura de toucinho, cujos aspectos importantes são a possibilidade de sua medição no animal vivo e sua favorável correlação com a maioria das características de carcaça (LOPES, FREITAS E FERREIRA., 1998).

Em razão do atual estilo de vida sedentário da população, que passou a ter maiores exigências com a carne magra, a partir dos anos 90 os programas de melhoramento genético de suínos passaram a dar grande ênfase na redução da espessura de toucinho.

A herdabilidade da característica $\left(\mathrm{h}^{2}=0,60\right)$ e sua alta associação genética com o conteúdo de carne na carcaça ( $r=0,80$, LABROUE, GUÉBLEZ e SELLIER., 1997), têm permitido obter ganhos genéticos significativos no aumento da deposição de carne nas carcaças, pela aplicação apenas de seleção massal para redução da espessura de toucinho.

Em 1990, a média de espessura de toucinho dos animais puros (granjas núcleo) estava em torno de $20 \mathrm{~mm}$ e, a partir de 2002, passou para menos de $10 \mathrm{~mm}$ (ABCS, 2000 e 2003). Além da seleção, outro fator que contribuiu para a queda na espessura de toucinho dos animais de abate (rebanho comercial) foi a introdução da raça Pietrain, em detrimento da Duroc. Em 1995, foram registrados no PBB (Pig Book Brasileiro) 6.533 suínos da raça Duroc e 638 da raça Pietrain, enquanto em 2003 foram registrados 1.861 suínos da raça Duroc e 4.173 da raça Pietrain (ABCS, 2003).

A gordura intramuscular ou marmoreio é um parâmetro considerado muito importante para a qualidade da carne de suínos, principalmente quando destinada ao consumo "in natura", sendo uma das principais características responsáveis pela maciez e suculência da carne suína. DE VRIES et al. (1994), relataram que as correlações fenotípicas e genéticas entre o rendimento de carne e a gordura intramuscular são negativas e moderadas, observando-se menor teor de gordura intramuscular em raças com alto rendimento de carne.

Nas últimas décadas, a alta seleção de suínos para genótipos relacionados à alta produção de carne magra, resultou na redução da gordura 
CAMPOS, P.F. et al. Impactos da seleção genética na qualidade da carne suína. PUBVET, Londrina, V. 8, N. 2, Ed. 251, Art. 1659, Janeiro, 2014.

subcutânea, mas também em uma diminuição drástica da gordura intramuscular. Foi demonstrado que os genes $F A B P_{3}$ e $F A B P_{4}$ têm influência na deposição de gordura intramuscular, com impacto limitado sobre a espessura e toucinho. Isto permite a seleção para aumento da gordura intramuscular, que melhora o sabor e a maciez, sem aumentar a espessura de toucinho (DEKKERS et al., 2004). O gene $\mathrm{FABP}_{4}$ de suínos foi isolado e seqüenciado por GERBENS et al. (1999), para estudo da sua função na diferenciação do acréscimo de gordura intramuscular nesses animais. Esses autores ao realizar um experimento com animais da raça Duroc concluíram que o locus $F A B P_{4}$ está envolvido na regulação do acréscimo de gordura intramuscular desses animais.

Pesquisas para este gene ainda estão sendo desenvolvidas para se obterem evidências de sua presença em raças puras, como a Duroc (GERBENS et al., 1999), o que poderia levar aos testes de DNA que permitissem o melhor controle do marmoreio da carne suína e de sua utilização comercial.

Outro desafio parece ser a identificação de genes ligados a maiores percentuais de gordura intramuscular, sem, no entanto, aumentar a deposição de gordura subcutânea, abdominal e intermuscular. Porém, as informações a respeito da localização desse gene são controversas.

Genótipos como o Duroc e seus cruzamentos estão entre as raças que apresentam o maior conteúdo de gordura intramuscular e cor, características desejáveis sob o ponto de vista do consumidor.

\subsection{Gene Halotano e carne PSE}

Também conhecido como gene do estresse, surgiu de uma mutação no cromossomo 6 do suíno e está associado com carne PSE (pálida, flácida e exudativa). Sua presença no suíno contribui para o aumento do percentual de carne na carcaça (FÁVERO, 1997), porém, provoca o aumento de mortes súbitas, especialmente na movimentação e transporte dos animais quando não manejados adequadamente.

O gene halotano tem sido explorado para condicionar aumento de carne na carcaça cruzando-se machos terminais heterozigotos $\left(\mathrm{Hal}_{\mathrm{Nn}}\right.$ ) com fêmeas 
CAMPOS, P.F. et al. Impactos da seleção genética na qualidade da carne suína. PUBVET, Londrina, V. 8, N. 2, Ed. 251, Art. 1659, Janeiro, 2014.

homozigotas livres do alelo recessivo $\left(\mathrm{Hal}_{\mathrm{NN}}\right)$. Esse procedimento objetiva chegar a uma progênie $50 \% \mathrm{Hal}_{\mathrm{Nn}}$ e $50 \% \mathrm{Hal}_{\mathrm{NN}}$, com um aumento de 1 a $2 \%$ no conteúdo de carne nas carcaças e, supostamente, sem prejuízo para a qualidade da mesma.

A utilização desse gene para a produção comercial acontece principalmente pela utilização de animais heterozigotos. A justificava para a utilização desse tipo de animal na produção comercial viria do intuito de aproveitar a superioridade desses, em relação aos homozigotos dominantes, no que diz respeito às características de carcaça e eficiência alimentar, ao mesmo tempo em que esses teriam uma menor incidência de PSE e de morte por estresse quando comparados com os homozigotos recessivos.

A raça Pietran foi usada para a obtenção de carcaças mais pesadas e de maior rendimento de carne magra. Entretanto, possui um elevado número de animais que são portadores do gene halotano.

As carnes PSE são caracterizadas por serem pálidas, flácidas e exsudativas (pale, soft and exsudative). Este defeito está relacionado com o genótipo de determinadas raças suínas. Principalmente naquelas que sofreram intensa seleção para melhorar a conversão alimentar em carcaça magra como o Pietran.

Com a sangria, se interrompe a oxigenação dos músculos paralisando a respiração celular e ocasionando na queda do potencial de óxido-redução dando início a glicólise anaeróbica o que torna difícil a reposição de ATP devido a ação da ATPase sarcoplasmática levando ao aumento do fosfato inorgânico que estimula a degradação do glicogênio. A glicólise anaeróbica e a fosfocreatina tentam produzir ATP, mas este se esgota rapidamente levando a inextensibilidade dos músculos (PARDI et al.,2001).

Em condições normais após o abate, o que resta de glicogênio dentro do músculo e se o retículo sarcoplasmático funciona corretamente, a diminuição do $\mathrm{pH}$ se faz lentamente até atingir o valor final. Em suínos, uma mutação no gene RYR1 (receptor de rianodina tipo 1) leva à PSS (Síndrome do Estresse Suíno) e às carnes PSE. A RyR1 é uma proteína formadora do canal de 
CAMPOS, P.F. et al. Impactos da seleção genética na qualidade da carne suína. PUBVET, Londrina, V. 8, N. 2, Ed. 251, Art. 1659, Janeiro, 2014.

liberação de $\mathrm{Ca}^{2+}$ no retículo sarcoplasmático de células musculares. Em suínos com a mutação neste gene o estresse desencadeia um acúmulo intracelular de $\mathrm{Ca}^{2+}$, e consequentemente a uma contração muscular permanente.

Esta elevação na concentração de íons $\mathrm{Ca}^{++}$no sarcoplasma prolonga a estimulação da atividade contrátil do músculo e estimula também, um rápido desdobramento de glicogênio para o relaxamento do músculo, resultando em exacerbação do metabolismo com produção de calor (MICKELSON e LOUIS, 1992).

Em carne de suínos portadores do gene Haln, heterozigotos (HalNn) ou homozigotos recessivos (Halnn) expostos a fatores estressantes no período que antecede o abate apresentam alterações musculares muito rapidamente após a sangria. Isso ocorre em função da liberação muito mais rápida de íons $\mathrm{Ca}^{++}$pelo retículo sarcoplasmático do que em animais normais. A concentração de íons cálcio no sarcoplasma se eleva muito acima da quantidade necessária para iniciar um ciclo de contrações e a alta atividade enzimática da ATPase de $\mathrm{Ca}^{++}$da membrana do retículo sarcoplasmático (bomba de cálcio) que se observa nessa situação, não é suficiente para restaurar a concentração de íons $\mathrm{Ca}^{++}$no sarcoplasma até níveis de repouso ou relaxamento muscular (RUBENSAM, 2000).

A súbita elevação de íons $\mathrm{Ca}^{++}$no sarcoplasma aumenta a velocidade de utilização do ATP muscular e da glicogenólise e com isso, a velocidade de declínio do $\mathrm{pH}$ é acelerada. A carne pode atingir valores iguais ou mesmo inferiores a 5,8 em menos de uma hora post mortem ( $\mathrm{pH} 45 \pm 5,8)$. Neste momento, a temperatura da carcaça encontra-se em torno de $36^{\circ} \mathrm{C}$ ou mais, dependendo dos estímulos recebidos pelo animal antes do abate e de como o animal responde aos mesmos.

Nos músculos onde predominam fibras brancas ou de contração rápida, o $\mathrm{pH}$ final atinge valores de 5,5 nas carnes de bovino e frango e 5,8 na carne de peru enquanto nos músculos de contração lenta (fibras vermelhas), o pH final fica mais alto sendo 6,$3 ; 6,1$ ou 6,4 . São também variáveis a temperatura que ocorre o processo post mortem e fatores de estresse (ORDOÑEZ et al., 2005). 
CAMPOS, P.F. et al. Impactos da seleção genética na qualidade da carne suína. PUBVET, Londrina, V. 8, N. 2, Ed. 251, Art. 1659, Janeiro, 2014.

No músculo PSE tem-se encontrado elevada atividade ATPasica e de enzimas glicolíticas.

No soro destes animais encontram-se maior quantidade de creatinofosfoquinase, este último achado coincide com o fato de que no momento do abate, o conteúdo de creatina e fosfato está reduzido nestes animais. Significa que a utilização de glicogênio começa antes, em músculos PSE, levando a uma rápida queda do pH (PRÄNDL, 1994).

A combinação do $\mathrm{pH}$ baixo e da elevada temperatura destas carnes causa uma maior desnaturação das proteínas miofibrilares. Estas carnes apresentam um $\mathrm{pH}$ em torno de 5.5, muito próximo ao ponto isoelétrico das proteínas miofibrilares. Neste $\mathrm{pH}$, estas proteínas, por terem cargas positivas e negativas em igual quantidade, apresentam uma aproximação máxima dos filamentos grossos e finos. Fazendo com que o espaço entre eles diminua ou até desapareça, impossibilitando a ligação destas moléculas com a água, reduzindo sua capacidade e estabilidade de retenção de água (CRA). A água fora das células e a estrutura protéica extremamente fechada provocam a reflexão da luz incidente fazendo com que as carnes PSE sejam extremamente pálidas. O maior defeito das carnes PSE é a exsudação. Nestas carnes, a água encontra-se pouco ligadas às proteínas, as membranas plasmáticas também são mais permeáveis. A exsudação pode ser explicada pela desnaturação das proteínas (ROSENVOLD e ANDERSEN, 2001).

\subsection{Gene da carne ácida}

As características de qualidade das "carnes ácidas" são semelhantes às das carnes PSE sendo detectadas, porém somente no final do resfriamento das carcaças, quando apresentam valores de $\mathrm{pH}$ final muito abaixo do normal, igual a 5,4 ou menos.

A velocidade de declínio do $\mathrm{pH}$ nestas carnes é normal, mas a intensidade com que ocorre o desdobramento do glicogênio muscular é muito maior do que em suínos normais. Por isso, esta característica se manifesta tardiamente após o abate. 
CAMPOS, P.F. et al. Impactos da seleção genética na qualidade da carne suína. PUBVET, Londrina, V. 8, N. 2, Ed. 251, Art. 1659, Janeiro, 2014.

É um gene dominante que se caracteriza por causar um decréscimo no rendimento industrial durante o processamento de produtos curados e cozidos, graças a um pH último reduzido, provocado pelo alto conteúdo de glicogênio nas fibras brancas dos músculos.

Altos valores de potencial glicolítico estão relacionados ao alelo dominante RN. Animais com alto potencial glicolítico nos músculos são classificados como homozigotos dominantes $\left(\mathrm{RN}^{-} \mathrm{RN}^{-}\right)$ou heterozigotos ( $\mathrm{RN}^{-}$ $\left.\mathrm{rn}^{+}\right)$. Animais homozigotos recessivos $\left(\mathrm{rn}^{+} \mathrm{rn}{ }^{+}\right)$são classificados como normais, produzindo carne com características de qualidade normais.

$O$ efeito do gene $\mathrm{RN}^{-}$se manifesta pelo aumento da concentração de glicogênio muscular, em torno de $70 \%$ acima do valor normal encontrado em suínos rn-rn-, no músculo Longissimus dorsi, típico "músculo branco" (SELLIER, 1994).

DE VRIES et al. (1998) referem-se a uma perda de 5 a $6 \%$ no processamento de presunto cozido derivado de genótipos portadores do gene $\mathrm{RN}^{-}$, além de uma perda significativa durante o fatiamento.

A frequência desse gene é alta na raça Hampshire, o que levou alguns pesquisadores a identificá-lo como efeito Hampshire. Entretanto, a presença do alelo $\mathrm{RN}^{-}$permitia um aumento no ganho médio diário e o conteúdo de carne magra na carcaça, o que dificultou o processo de reconhecimento do efeito maléfico causado por tal gene em termos de qualidade de carne.

Acreditava-se até bem pouco tempo, tratar-se de um problema restrito a populações de Hampshire, porém um trabalho conduzido por MEADUS et al. (2000) no Canadá, mostrou a presença do gene RN- em populações comerciais de suínos brancos, provavelmente em decorrência do intenso uso de machos terminais da raça Hampshire.

A partir do trabalho de MEADUS et al. (2000) foi desenvolvido um teste de DNA que permite identificar os animais portadores do gene $\mathrm{RN}^{-}$, o que permite eliminá-lo nos plantéis de seleção. 
CAMPOS, P.F. et al. Impactos da seleção genética na qualidade da carne suína. PUBVET, Londrina, V. 8, N. 2, Ed. 251, Art. 1659, Janeiro, 2014.

\subsection{Influência do tipo de fibra muscular na qualidade da carne}

O tecido muscular é composto basicamente por três tipos de fibras musculares: oxidativas de contração lenta (Tipo I, vermelhas e aeróbicas), intermediárias de contração rápida (Tipo II $B$, oxidativas glicolíticas) e as glicolíticas de contração rápida (Tipo II A, brancas, anaeróbicas).

As características fisiológicas e metabólicas e o tamanho final do tecido muscular, uma vez cessado o crescimento, dependem grandemente da proporção dos tipos de fibras. A freqüência de ocorrência de cada tipo de fibras no músculo é influenciada pela genética, nutrição e manejo dos animais.

Os músculos que contêm muitas fibras do tipo I são chamados de músculos vermelhos, por serem mais escuros do que os outros músculos. Os músculos vermelhos, que respondem lentamente e têm grande latência, são adaptados para contrações duradoras, lentas, mantenedoras da postura. Os longos músculos do dorso são músculos vermelhos.

Os músculos brancos, que contêm maior número de fibras tipo II, têm abalos rápidos e são especializados para movimentos finos e dependentes de habilidade. Os músculos extra-oculares e alguns dos músculos da mão contêm muitas fibras do tipo II.

As fibras vermelhas tendem a ser menores, contêm mais mitocôndrias, concentrações maiores de mioglobina e lipídios e uma irrigação sanguínea mais abundante porque grande parte de sua energia provém do metabolismo aeróbico. Estas fibras estão adaptadas para a contração lenta por um longo período de tempo.

Os músculos brancos possuem maiores quantidades de glicogênios e enzimas relacionadas com a glicólise anaeróbica. Estas fibras estão adaptadas para a contração rápida por curto período de tempo. Também possuem baixa concentração de mioglobina, uma vez que ela é necessária para armazenamento de oxigênio o que não é necessário em fibras glicolíticas.

$\mathrm{Na}$ Tabela 1 são apresentadas algumas características das fibras musculares. 
CAMPOS, P.F. et al. Impactos da seleção genética na qualidade da carne suína. PUBVET, Londrina, V. 8, N. 2, Ed. 251, Art. 1659, Janeiro, 2014.

Tabela 1 - Características das fibras musculares vermelhas, intermediárias e brancas de animais de abate.

\begin{tabular}{cccc}
\hline Característica & Fibras Vermelh & $\begin{array}{c}\text { Fibras } \\
\text { Intermediárias }\end{array}$ & $\begin{array}{c}\text { Fibras } \\
\text { Brancas }\end{array}$ \\
\hline $\begin{array}{c}\text { Cor } \\
\text { miogleúdo de }\end{array}$ & Vermelha & Vermelha & Branca \\
$\begin{array}{c}\text { Diâmetro da fibra } \\
\text { Velocidade de }\end{array}$ & Pequeno & Alto & Baixo \\
contração & Lenta & Rápida & Rápida \\
Tipo de contração & Tônica & Tônica & Fásica \\
Numero de & Alto & Intermediário & Baixo \\
mitocôndrias & & & Pequeno \\
Tamanho & Grande & Intermediário & \\
mitocondrial & & & Baixa \\
Densidade capilar & Alta & Intermediária & Escasso \\
Metabolismo & Abundante & Intermediário & \\
oxidativo & & & Baixo \\
Metabolismo & Escasso & Intermediário & Abundante \\
glicolítico & & Antermediário & \\
Conteúdo lipídico & Alto & Alto & \\
Conteúdo & Baixo & & \\
glicogênico & & & \\
\hline
\end{tabular}

Fonte: (JUDGE et al., 1989)

A composição das fibras que compõem um músculo está diretamente relacionada com a qualidade final e as propriedades tecnológicas da carne, sendo que a freqüência de ocorrência de cada tipo de fibras no músculo pode ser influenciada por diversos fatores como: genética, gênero, maturidade, nutrição e manejo adequado. 
CAMPOS, P.F. et al. Impactos da seleção genética na qualidade da carne suína. PUBVET, Londrina, V. 8, N. 2, Ed. 251, Art. 1659, Janeiro, 2014.

As fibras glicolíticas possuem maior área e velocidade de crescimento que as fibras glicolíticas e, portanto a seleção de suínos visando o aumento da deposição de músculo leva a um aumento na frequência de células glicolíticas no músculo. Estudos realizados por DALL PAI e CURI (1992), mostram um maior crescimento dos músculos com maior quantidade de fibras brancas, e afirmam que fibras brancas possuem maiores taxas geométricas de crescimento.

O tipo de fibra muscular pode exercer grande influência sobre a qualidade da carne devido ao metabolismo post mortem. As fibras brancas possuem predominantemente um metabolismo anaeróbico para a produção de ATP a partir do glicogênio muscular, que leva a um aumento na produção de ácido lático pós-mortem, o que resulta em valores de $\mathrm{pH}$ do músculo mais baixos que as fibras vermelhas. No processo de transformação do músculo em carne, o ácido lático, não pode ser retirado do músculo e ali se acumula, uma vez que não há mais fluxo sanguíneo, promovendo o declínio do $\mathrm{pH}$ e acidificação da carne. Quando a produção de ácido lático é muito rápida na primeira hora após o abate, associado com a temperatura elevada da carcaça pode resultar em carnes com anomalia do tipo PSE (do inglês pale, soft and exsutative).

Dessa forma, animais mais musculosos com maior taxa de crescimento, apresentam maior proporção de fibras glicolíticas, portanto carne mais clara e com menor capacidade de retenção de água.

\section{Conclusão}

O consumidor está cada vez mais exigente em carne de qualidade em relação à cor, consistência, sabor, valor nutricional, segurança alimentar e preço. Os distribuidores exigem da indústria, produtos que atendam às necessidades dos consumidores. Os produtores, por sua vez, necessitam produzir animais que produzam carne de boa qualidade a um custo mínimo. 
CAMPOS, P.F. et al. Impactos da seleção genética na qualidade da carne suína. PUBVET, Londrina, V. 8, N. 2, Ed. 251, Art. 1659, Janeiro, 2014.

A carne de suínos atuais selecionados para alto crescimento e deposição de carne magra na carcaça, têm se mostrado de qualidade inferior, com menor taxa de marmoreio, menor maciez e coloração mais pálida.

Dessa forma, é de extrema importância que se tenha um programa de melhoramento genético voltado não só para a qualidade da carcaça, mas também que atenda os requisitos exigidos para uma melhor qualidade da carne.

\section{Referências Bibliográficas}

$A B C S$. Relatório de registro genealógico e de provas zootécnicas. Associação Brasileira de Criadores de Suínos, 2000.

$A B C S$. Relatório de registro genealógico e de provas zootécnicas. Associação Brasileira de Criadores de Suínos, 2003.

DABÉS, A. C. Propriedades da Carne Fresca. Revista Nacional da Carne, n.228, p. 32-40, 2001.

DAL PAI, V.; CURI, P.R. Crescimento pós-natal do coelho Norfolk: Correlação entre parâmetros somáticos e área dos tipos de fibras musculares. Pesquisa Agropecuária Brasileira, v.27, p.1623-33, 1992.

DE VRIES, A.G.; VAN DER WAL, P.G.; LONG, T. et al. Genetic parameters of pork quality and production traits in Yorkshire populations. Livestock Production Science, v.40, p.277-289, 1994.

DE VRIES, A.G.; SOSNICKI, A.; GARNIER, J.P. et al. The role of major genes and DNA technology in selection for meat quality in pigs. Meat Science, v.49, p.245-255, 1998.

DEKKERS, J. C. M. Commercial application of marker- and gene-assisted selection in livestock: Strategies and lessons. Journal of Animal Science, v. 82, p.313- 328, 2004.

FAVERO, J.A Influencia do gene halotano sobre o desempenho produtivo de suínos. In: $8^{\circ}$ Congresso Nacional da Associação Brasileira de Veterinários Especialistas em Suínos. Foz do Iguaçu. Anais... ABRAVES. p.395-396, 1997.

GERBENS, F.; VAN ERP, A. J.; HARDERS. et al. Effect of genetic variants of the heart fatty acid-binding protein gene on intramuscular fat and performance traits in pigs. Journal of Animal Science, v. 77, p. 846-52, 1999.

JUDGe, M.D.; ABERLE, E.D.; FORREST, J.C; et al. Principles of meat science. 2.ed. Dubuque, Kendall/ Hunt Publishing Company, 351 p, 1989.

LABROUE, F.; GUÉBLEZ, R.; SELLIER, P. Genetic parameters of feeding behavior and performance traits in group-housed Large White and French Landrace growing pigs. Genétics Selection Evolution, v. 29, p. 451-468, 1997. 
LOPES. P.S.; FREITAS, R.T.F.; FERREIRA, A.S. Melhoramento de suínos. UFV. 39 p.(Caderno Didático, 37). 1998.

MEADUS, W.J.; MACINNIS, R.; AALHUS, J.L. Alberta pork tests positive for the "acid meat" phenotype. Disponível em: http://www.afns.ualberta.ca Acessado em: 08 de julho de 2013.

ORDOÑEZ PEREDA, J. A.; RODRIGUeZ, M. I. C.; ALVAREZ, L. F. et al. Tecnologia de alimentos -Alimentos de origem animal, Porto Alegre: Artmed, v. 2, 279p, 2005.

PARDI, M.C.; SANTOS, I.F.; SOUZA, E.R. et al. Ciência, Higiene e Tecnologia da Carne. Goiânia:CEGRAF - UFG/ Niterói: EDUFF, v. 1, 623p, 2001.

PRÄNDL, O.; FISHER, A. ; SCHIMIDHOFER, T. et al. Tecnologia e ciência de la carne. Editorial Acribia, S.A. Zaragosa, España, 592p, 1994.

ROSENVOLD, K.; ANDERSEN, H. J. Factors of significance for pork quality: a review. Meat Science, v 59, p. 397-406, 2001.

RUBENSAN, J. M. Transformações pós-mortem e qualidade da carne suína. In. $1^{a}$ Conferência Internacional Virtual sobre Qualidade de Carne Suína. Concórdia. Anais... EMBRAPA, p. 89-98, 2000.

SELLIER, P. The future role of molecular genetics in the control of meat production and meat quality. Meat Science, v.36, p.29-44, 1994.

VALENTINE, R. Suínos: foco nas exportações. O Estado de São Paulo, folha agrícola de 26 de Outubro de 2005. p G9. 